\title{
Unemployment Hysteresis Revisited: The Case of Turkey
}

\author{
Ph.D. Candidate Ufuk Can (Çukurova University, Turkey) \\ Ph.D. Candidate Zeynep Gizem Can (Çukurova University, Turkey) \\ Prof. Dr. Harun Bal (Çukurova University, Turkey)
}

\begin{abstract}
This study aims to investigate the stability of unemployment rate in Turkey with the data set covering approximately a century and starting from 1923. The stability of the unemployment rate is examined the unit root tests, the variance ratio tests and the fractional integration models by following the studies in the literature. Almost all tests and models indicate that the unemployment rate series is not stationary. These findings show that the shocks in the economy and the stabilization policies implemented bring about permanent changes in the natural rate of unemployment. While the unemployment hysteresis leads to increasing costs in reducing inflation, it also reveals the necessity of structural reforms to reduce increased unemployment as a result of inflation control or changes in structural factors. In order to eliminate the impact of this hysteresis on economy, it is necessary to give weight to the expansionary monetary and fiscal policies, which in the short term may be costly, but this impact can be eliminated in the long term.
\end{abstract}

\section{Theoretical Framework}

Unemployment can be defined as the idleness of labor due to the various reasons such as shortage of demand, lack of accumulation and low mobility. Unemployment is one of the most researched topics by economists, due to its financial and social damages, that's why all schools of economics put forth theories trying to explain the topic. To put it chronologically, in the neoclassical school, unemployment is defined as the unavailability of work despite of the fact that there is a desire to work at the prevailing level of wages and search for employment, meaning that it is the case of being out of work involuntarily. It is said that there is always full employment within the economy via the invisible hand mechanism, but the existence of both short-term frictional unemployment that can stem from job circulation or mobility and long-term unemployment that can arise from the structural changes within the economy and changes of demand is acknowledged. The fact that the neoclassical school could not explain substituting role of the automation in place of labor during production process and the rise of the concept of technological unemployment is seen as the shortcoming of the school and the Marxist economic theory steps in. According to Marxist theory, which is based on labor theory of value, value of any good is determined by the indirect labor which includes production factors except labor and the direct labor which produces the good by using other production factors. According to Marx who describes the indirect labor within production factors as unchanged or fixed capital and the value of the direct labor as variable capital, capital accumulation process and automation gives rise to the emergence of spare labor and downside pressure on real wages. The increasing organic blending of the technology and capital makes investment lessen and causes unemployment by decreasing profit margins.

The Great Depression which starts in 1929 and Keynes' General Theory of 1936 dramatically changes points of view on unemployment. Keynesian school analyzes underemployment by emphasizing imperfect competition conditions, sticky prices and wages and involuntary unemployment. According to Keynes who contributes to the literature by defining the unemployment which changes based on cyclical fluctuations as conjunctural unemployment, unemployment is an outcome of the insufficient demand. Keynes, stating that firms demand less labor because of the fact that individuals demand fewer goods, is of the view that government must intervene in markets to find a solution for the unemployment problem. Although the Keynesian viewpoint on unemployment prevails until the oil shocks, the studies that try to understand dynamic nature of the unemployment steps up as a global unemployment wave spreads out due to oil shocks. The pioneers of monetarist and neoclassical schools, Phelps (1967, 1968), Friedman (1968) and Phelps (1994) state that unemployment rate would incline to return to it is long-run equilibrium level. Assuming that natural or nan-accelerating inflation rate of unemployment (NAIRU) and prevalent unemployment rate may differ, it is asserted that unemployment rate would come back to it is natural level although there may be an adverse relationship between inflation and unemployment rates in the short run as stated in the Philips Curve. Blanchard and Summers (1986), as the representatives of the NeoKeynesian School which try to examine substantial increases in the current account deficits and unemployment rates of various countries, asserts that unemployment rate may diverge from the natural level in the long-run in a persistent way. The case of persistently high unemployment rate is called as unemployment hysteresis, meaning that cyclical fluctuations have a constant impact on unemployment in the countries where the labor market is inflexible and that's why series of unemployment are not stationary (Christopoulos and León-Ledesma, 2007). This hypothesis, which asserts there is not only one natural unemployment rate, requires that the series of unemployment rate have unit-root from an econometric perspective (Stanley, 2004). Unemployment hysteresis can be formulated as follows (Song and $\mathrm{Wu}, 1998)$ : 
$u_{t}^{*}=u_{t-1}{ }^{*}+\rho\left(u_{t-1}-u_{t-1}^{*}\right)$

where $u_{t}{ }^{*}, u_{t-1}{ }^{*}$ and $u_{t-1}$ represents present unemployment rate, natural rate of unemployment rate in the previous periods and actual unemployment rates in the previous periods respectively. If $\rho \neq 0$, natural unemployment rate partially converges to actual one and this situation does not confirm the hypothesis of unemployment hysteresis. On the other hand, natural unemployment rate does not converge to actual one and the hypothesis of unemployment hysteresis is validated if $\rho=0$.

The lasting effects of external shocks on unemployment hysteresis are explained via various theories. Pissarides (1992) stresses that the unemployed loses their abilities as well as their motivations and the period of benefiting unemployment insurance negatively affects the unemployed's re-entry desire into labor market. Furthermore, the theory of insider-outsider put forth by Lindbeck and Snower (1986) assumes that insiders(employed) does not care about outsiders (unemployed) and only think of themselves. According to the theory, while some people lose their jobs in case of a negative economic shock, insiders care about their own interests only and ask for new employment contracts which call for higher wages. Since unionized insiders would have more bargaining powers against firms, while the outsiders would need time and training to learn how to do job, firms would be forced to accept the demands of the insiders. In addition, the rise in layoff costs, capital shortages, failures in coordination and the factors like stigma effects of unemployment may be the causes of unemployment hysteresis (Christopoulos and León-Ledesma, 2007).

Various models are frequently used for the purpose of testing natural unemployment rate and hysteresis such as traditional models, breakpoint unit root tests, panel and non-linear unit root tests, variance ratio tests and long memory models. As the new developments arise in econometrics they are also applied on updated time series. Once unemployment rate series are stationary, it's accepted that natural unemployment hypothesis is valid. If there is unit root problem in unemployment rate series, it's accepted that unemployment rate does not incline to converge to its equilibrium level in the wake of an external shock and this situation supports the existence of unemployment hysteresis. The fact that shocks have lasting on unemployment necessitates governments to intervene in economy by designing and implementing policies that will solve unemployment problem, especially in recessionary periods of time, economic damages that the unemployment would cause would aggravate in line with the existence of unemployment hysteresis.

Unit root tests are the most frequently used method in testing the unemployment hysteresis hypothesis in the literature. Blanchard and Summers (1986), Neudorfer et al. (1990) and Roed (1996) conduct traditional unit root tests which are based on the testing of null hypothesis $\rho=0$ on unemployment rate series.

$\Delta \mathrm{u}_{\mathrm{t}}=\alpha+\rho \mathrm{u}_{\mathrm{t}-1}+\sum_{\mathrm{i}=1}^{\mathrm{k}} \Delta \mathrm{u}_{\mathrm{t}-\mathrm{i}}+\epsilon_{\mathrm{t}}$

Gustavsson and Osterholm (2006), Chang (2011) and Ozkan and Altınsoy (2015) test unemployment hysteresis by means of nonlinear unit root tests. Due to the fact that traditional unit root tests may have biased outcomes in case of data constraints, the variables that affect unemployment rate may differentiate and the difficulties faced in collecting data, unit root tests, which are trusted more in relation to traditional unit root tests, would be required to be used to test the stationarity of unemployment rate. If it is assumed that unemployment rate does not have a linear structure due to economic shocks and government policies, nonlinear models, simply, are based on the testing null hypothesis $\theta=0$.

$u_{t}=\alpha+\tau\left[1-\exp \left(-\theta u_{t-1}^{2}\right)\right] u_{t-1}+\epsilon_{t}$

On the other hand, the said null hypothesis does not provide any information related to the coefficient, $\tau$, the equation may be rewritten thanks to Taylor method and null hypothesis $\delta=0$ is tested.

$\Delta u_{t}=\delta u_{t-1}^{3}+\epsilon_{t}, \quad \delta=\tau \theta$

Gomes and Silva (2008), Y1lancı (2009) and Lee et al (2010) tests the validity of unemployment hysteresis via breakpoint unit root tests which take structural breaks into consideration. This method is based on testing the breaks in the breakpoint and trend, assuming that short term economic shocks or structural breaks may make unemployment rate deviate from its long term equilibrium, under the assumption of existence of structural breaks in unemployment rate series.

$\Delta u_{t}=\alpha+\rho u_{t-1}+\vartheta_{1} D U(\theta)+\vartheta_{2} D V(\theta)+\sum_{i=1}^{k} \Delta u_{t-i}+\epsilon_{t}$

Song and $\mathrm{Wu}$ (1998), Johansen (2002), Gozgor (2012) use panel unit root tests which don't take structural breaks into consideration to test the hypothesis of unemployment hysteresis, whereas, Christopoulos and León-Ledesma (2007), Guloglu and Ispir (2011) use panel root tests which take structural breaks into consideration. These tests are demonstrated as similar to the equations (2) and (5), except $\mathrm{m}$ panel data are shown by generalizing like $\mathrm{j}=1$, $2, \ldots, \mathrm{m}$.

In addition to unit root tests, Fève et al. (2003) and Mikhail et al. (2005) use variance ratio tests. Unemployment rate has a random walk process since its $\mathrm{k}^{\text {th }}$ order differential variance is $\mathrm{k}$ times its first order differential variance (Cochrane, 1988).

$\operatorname{Var}\left(V_{t}-V_{t-k}\right)=k \cdot \operatorname{Var}\left(V_{t}-V_{t-1}\right)$ 
Accordingly, in the null hypothesis that can be reorganized as $\operatorname{VR}=(1 / k) \cdot \operatorname{Var}\left(V_{t}-V_{t-k}\right) / \operatorname{Var}\left(V_{t}-V_{t-1}\right)$, the fact that variance ratio(VR) smaller than 1 means that unemployment rate is stationary and mean-reverting, while the fact that VR is equal to 1 means that unemployment rate has a random walk process. If VR is greater than 1 , it means that unemployment rate is super-persistent in not-reverting to the mean.

Lastly, Crato and Rothman (1996), Gustavsson and Österholm (2006), and Kurita (2010) explain long term memory in unemployment rate series by using Autoregressive Fractional Integrated Moving Average (ARFIMA) Model developed by Granger and Joyeux (1980), Granger (1980) and Hosking (1981). In ARFIMA (p, d, r) model, $\mathrm{d}, \mathrm{L}$ and $\mu$ signify degree of integration, lagging operator and mean respectively, while $\Phi(\mathrm{L})$ and $\Theta(\mathrm{L})$ stand for lag polynomials.

\begin{tabular}{ll}
$\Phi(L)(1-L)^{d}\left(q_{t}-\mu\right)=\Theta(L) \epsilon_{t}, \quad \epsilon_{t}=$ i.i.d. $\left(0, \sigma^{2}\right)$ \\
\hline $\mathbf{d}$ & Unemployment Rate \\
\hline $\mathbf{1} \mathbf{1 , 0}$ & Unemployment rate is not stationary \\
$\mathbf{0 , 5 - 1 , 0}$ & Deviations mean-reverting, but not stationary \\
$\mathbf{0 - 0 , 5}$ & Deviations mean-reverting and stationary in the long term \\
$\mathbf{0}$ & Deviations stationary and mean-reverting. Unemployment rate is stationary. \\
\hline
\end{tabular}

Table 1. Relationship between the Parameter d and Unemployment Rate Source: Villeneuve and Handa (2006)

\section{Data and Methodology}

The unemployment rate series examined in this study consist of 96 annual observations from 1923 to 2018. Data are compiled from Bulutay (1995) and TURKSTAT. Bulutay (1995) assumes that investment per capita in fixed prices can be used as a basis for determining the unemployment rate and he calculated the unemployment rate series for period 1923-1995 by dividing the number of unemployed given by DE (1988) in the relevant years to the change in the investment index per capita. The unemployment rate data in the joint years are consistent with the data announced by TURKSTAT and the data after 1995 are compiled from TURKSTAT. The unemployment rate $\left(u_{t}\right)$ is shown in Figure 1.

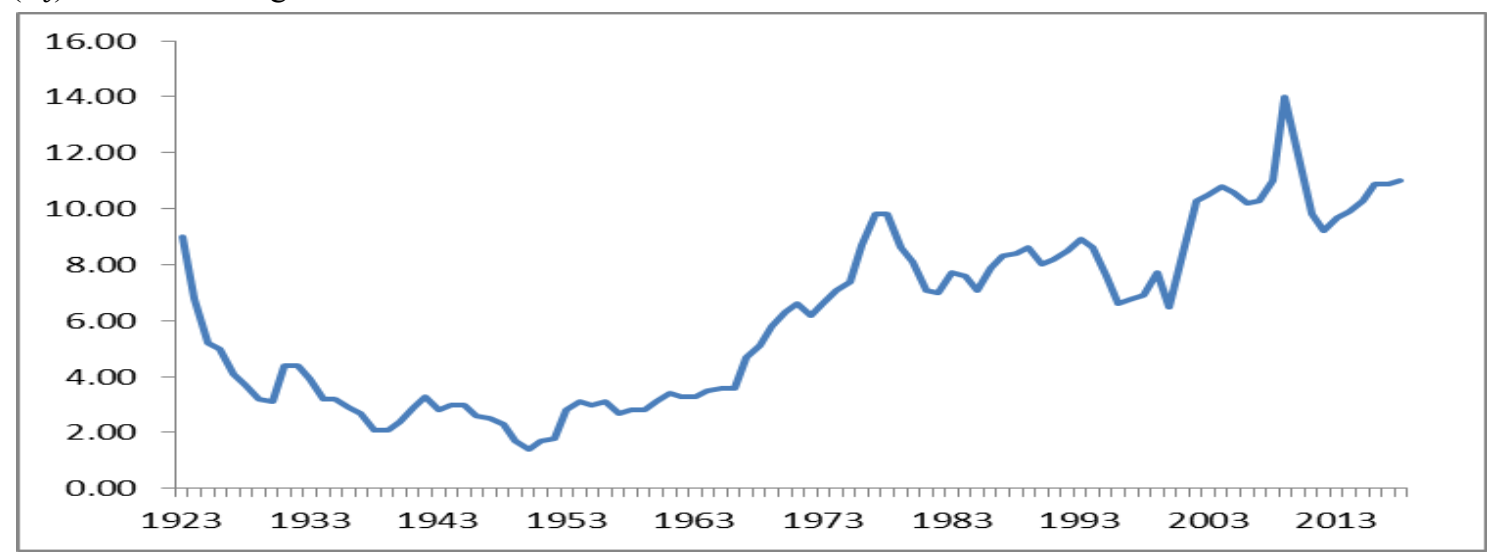

Figure 1. Unemployment Rate (1923-2018)

Traditional, breakpoint and nonlinear unit root tests, variance ratio tests and autoregressive fractional integrated moving average (ARFIMA) model are used in the literature to test the validity of the unemployment hysteresis hypothesis. Firstly, the stability of the $u_{t}$ series is analyzing with the help of Dickey-Fuller (Augmented DickeyFuller, ADF) by formulating Dickey and Fuller (1981), Dickey-Fuller Generalized Least Squares (DF-GLS) proposed by Elliott et al. (1996), Phillips-Perron (PP) developed by Phillips and Perron (1988), Ng -Perron (NP) formulated by $\mathrm{Ng}$ and Perron (2001) and Kwiatkowski-Phillips-Schmidt-Shin (KPSS) developed by Kwiatkowski et al. (1992) traditional unit root tests. The optimal lag length in ADF and DF-GLS tests is determined by the method of Lagrange Multiplier (LM) and by the General-to-Specific (GtoS) method proposed by Hall (1994), as well as by the modified Akaike Information Criteria (MAIC) developed by $\mathrm{Ng}$ and Perron (1995).

The fact that the unemployment rate series is exposed to structural breakpoints in the period makes the results of the traditional unit root test suspicious. Therefore, the stability of the $u_{t}$ series is re-examined in three groups by unit root tests taking into account the existence of structural breaks. In the first group, the breakpoint unit root tests based on Perron (1989) and developed by Perron and Vogelsang (1992), Perron (1997) and Clemente et al. (1998) are applied. The Perron-Vogelsang (PV) and Perron tests allow for a single break, while the ClementeMontanes-Reyes (CMR) test allows for two breaks. In the second group, the breakpoint unit root tests based on ADF test and developed by Zivot and Andrews (1992), and Lumsdaine and Papell (1997) are applied. The Zivot 
and Andrews (ZA) test allows for a single break, while the Lumsdaine and Papell (LP) test allows for two breaks. In the third and the last group, the stationary of $u_{t}$ series is examined by the breakpoint unit root tests based on LM test and developed by Lee and Strazicich (2004) allowing for a single break, and Lee and Strazicich (2003) allowing for two breaks.

While traditional and breakpoint unit root tests are applied, the $u_{t}$ series is assumed to be linear. Therefore, Kapetanios-Shin-Snell (KSS) test based on exponential smooth transition autoregressive (ESTAR) proposed by Kapetanios et al. (2003) and Sollis test based on asymmetric exponential smooth transition autoregressive (AESTAR) formulated by Sollis (2009) are applied against nonlinearity.

Unit root tests necessitate an integer degree of integration of a series (d). In fact, most of the economic and financial time series are not conformity with neither zero order $(\mathrm{I}(0))$, nor the first order $(\mathrm{I}(1))$ process (Banerjee and Urga, 2005). ARFIMA models, unlike unit root tests, allow the degree of integration to take real values. In these models, the null hypothesis $\left(H_{0}: d=0\right)$ in which the $u_{t}$ series is stationary can be tested directly, but the null hypothesis $\left(H_{0}: d-1=0\right)$, which is not stationary like the unit root tests, can be tested. Following Baum et al. (1999), $d^{*}$ parameter is predicted with semi-parametric approach developed by Geweke and Porter-Hudak (1983), Robinson (1995) and Phillips (1999a, b) by taking the first difference of q series while $d^{*}=d-1$.

Unit root tests allow testing between two endpoints that a series is either stationary or not stationary. However, the series can contain both stationary and non-stationary elements. If a series has these two elements simultaneously, unit root tests have a tendency not to reject the null hypothesis that the series is not stationary (Maeso-Fernandez, 1998). Therefore, variance ratio tests are used to determine the non-stationary element in a series. Firstly, it is investigated whether the $u_{t}$ series follows the random walking process under homoscedasticity and heteroscedasticity as suggested by Lo and MacKinlay (1988). Secondly, rank, rank score and sign tests developed by Wright (2000) are applied.

Before the econometric analysis, Figure 1 shows that the downward trend in the unemployment rate seen until the 1950s was later replaced by the upward trend. $u_{t}$ series is not stationary and therefore the unemployment hysteresis hypothesis is valid in Turkey. In fact, when the correlogram of $u_{t}$ series is examined, the autocorrelation function decreases very slowly and it takes a long time for any shock to disappear its effect on the $u_{t}$ series (Table 2). This increases the probability of nonstationary of $u_{t}$ series.

\begin{tabular}{llllllll}
\hline $\mathbf{k}$ & AC & Q-stats & Prob. & Lags & AC & Q-stats & Prob. \\
\hline 1 & 0.952 & 88.662 & 0.00 & 6 & 0.764 & 436.54 & 0.00 \\
2 & 0.896 & 169.97 & 0.00 & 7 & 0.743 & 494.83 & 0.00 \\
3 & 0.851 & 243.24 & 0.00 & 8 & 0.716 & 549.67 & 0.00 \\
4 & 0.816 & 311.30 & 0.00 & 9 & 0.675 & 598.94 & 0.00 \\
5 & 0.789 & 375.60 & 0.00 & 10 & 0.628 & 642.05 & 0.00 \\
\hline
\end{tabular}

Table 2. Correlogram of Unemployment Rate

Notes: (1) $k$ and $Q$ indicate the number of lags and the test statistics developed by Ljung and Box (1978) for testing the null hypothesis there is no autocorrelation until $k^{\text {th }}$ lags, respectively. (2) This test is performed with the help of Eviews 10.

\section{Empirical Findings}

Initially, the stationarity of the $u_{t}$ series is tested with the ADF, DF-GLS, PP, NP and KPSS traditional unit root tests with the optimal lag lengths determined by the LM, GtoS and MAIC information criteria. According to these methods, $u_{t}$ series is not stationary except for some of the ADF and PP test forms. KPSS test results is significant at $1 \%$ critical value, but unlike the other traditional unit root tests, KPSS test is stated that the series is stationary in $\mathrm{H}_{0}$ hypothesis and $\mathrm{H}_{1}$ hypothesis is not stationary in the series. It means this test cannot accept that $u_{t}$ series is stationary. Even though the traditional unit root tests indicate that the $u_{t}$ series are not stationary, the null hypothesis that $u_{t}$ series is not stationary cannot be rejected in the PV, CMR and LP tests with constant break, but rejected in other breakpoint unit root tests. Traditional and breakpoint unit root tests implicitly assume that the $u_{t}$ series is linear. KSS and Sollis tests taking into account the non-linearity of the $u_{t}$ series show that the $u_{t}$ series is not stationary.

Due to fact that unit root tests allow testing between two endpoints that a series is either stationary or not stationary and necessitate an integer degree of integration of a series (d), VR (Lo and MacKinlay, Wright, Chow and Denning) and ARFIMA (Geweke and Porter-Hudak, Robinson, Phillips) tests are applied to increase the reliability of unit root tests. As a result, the null hypothesis that $u_{t}$ series follows random processes cannot be rejected. 


\begin{tabular}{|c|c|c|c|}
\hline Tests & & Constant & Constant and Trend \\
\hline $\mathbf{A D F}_{L M}$ & & $-0.327(8)$ & $-3.003(8)$ \\
\hline ADFGtos $_{\text {G }}$ & & $-1.052(1)$ & $-3.775(1)^{* *}$ \\
\hline ADF $_{\text {MAIC }}$ & & $-0.667(2)$ & $-4.562(0)^{*}$ \\
\hline DF-GLSLM & & $-0.932(8)$ & $-0.961(8)$ \\
\hline DF-GLS GtoS & & $-1.175(1)$ & $-1.487(1)$ \\
\hline DF-GLSMAIC & & $-0.845(2)$ & $-1.066(2)$ \\
\hline PPMaic & & $-0.896(2)$ & $-4.562(0)^{*}$ \\
\hline \multirow{2}{*}{ NPMaIC } & $\mathbf{M Z a}$ & $-2.803(2)$ & $-2.351(0)$ \\
\hline & $\mathbf{M Z} \mathbf{Z}_{\mathrm{t}}$ & $-0.878(2)$ & $-1.017(0)$ \\
\hline KPSS MAIC $_{\text {M }}$ & & $116.20(2)^{*}$ & $5.614(0)^{*}$ \\
\hline
\end{tabular}

Table 3. Traditional Unit Root Tests

Notes: (1) The critical values are obtained from Fuller (1976) for ADF and PP tests, from Elliott et al. (1996) for DF-GLS test, from Ng and Perron (2001) for NP test and from Kwiatkowski et al. (1992) for KPSS test. (2) The number of observations for the ADF, DF-GLS and PP tests is accepted to be 100. (3) The critical values of $1 \%$ and $5 \%$ significance levels in ADF and PP tests are -3.51 and -2.89 , respectively, for models with only intercept, while -4.04 and -3.45 for models with intercept and trend. These critical values are, respectively, -2.58 and -1.94 and -3.58 and 3.03 for the DF-GLS test; -13.80 and -8.10 to -23.80 and -17.30 for $N P / M Z_{a},-2.58$ and -1.98 to -3.42 and -2.91 for $N P / M Z_{t} ; 0.739$ and 0.463 and 0.216 and 0.146 for the KPSS test, respectively. (4) OLS-detrended procedure is used in PP, NP and KPSS tests. (5) The values in parenthesis represent the optimal lag length. The maximum lag length is 8 . (6) * and ** indicate that the null hypothesis is rejected at $1 \%$ and $5 \%$ significance levels. (7) The tests are carried out with EViews 10.

\begin{tabular}{|c|c|c|c|c|}
\hline \multirow[t]{3}{*}{ Tests } & \multicolumn{4}{|l|}{ Intercept Break } \\
\hline & \multicolumn{2}{|l|}{ Additive Outlier } & \multicolumn{2}{|l|}{ Innovational Outlier } \\
\hline & t-stats & Break Dates & t-stats & Break Dates \\
\hline PV & $-4.045(1)^{* *}$ & 1970 & $-3.978(1)$ & 1965 \\
\hline CMR & $-2.972(6)$ & 1970,2003 & $-6.650(1)^{*}$ & 1965,1999 \\
\hline \multirow[t]{4}{*}{ Perron } & & & $-4.590(1)$ & 1966 \\
\hline & Trend Break & & \multicolumn{2}{|c|}{ Intercept and Trend Break } \\
\hline & Additive Outlier & & Innovational Outlier & \\
\hline & t-stats & Break Date & t-stats & Break Date \\
\hline Perron & $-4.204(1)$ & 1946 & $-4.922(1)$ & 1966 \\
\hline
\end{tabular}

Table 4. Breakpoint Unit Root Tests (Based on Perron)

Notes: (1) The critical values are obtained from Perron and Vogelsang (1992) for PV test, from Clemente et al. (1998) for CMR test, from Perron (1997) for Perron test. The number of observations for the PV and Perron tests is accepted to be 100. (2) The critical values of $1 \%$ and $5 \%$ significance levels in PV test are -4.38 and -3.64 , respectively, for models with only intercept break and additive outlier, while -4.95 and -4.22 for models with intercept break and innovational outlier. These critical values are, respectively, -5.96 and -5.49 for CMR test with intercept break both additive outlier and innovational outlier. The critical values of $1 \%$ and $5 \%$ significance levels in Perron test are -5.70 and -5.10 for models with only intercept break and innovational outlier, -5.45 and -4.83 for models with only trend break and additive outlier, while -6.21 and -5.55 for models with intercept and trend break and innovational outlier, respectively. (3) The PV and CMR tests include only intercept, while Perron test contains both intercept and trend. (4) The values in parenthesis represent the optimal lag length determined by the GtoS approach. The maximum lag length is $8 .(5) *$ and $* *$ indicate that the null hypothesis is rejected at $1 \%$ and $5 \%$ significance levels. (6) The trimming parameter is 0.15. (7) PV and CMR tests are performed by Stata 14.2 and Perron by Eviews 10.

\begin{tabular}{lllllll}
\hline \multirow{2}{*}{ Tests } & \multicolumn{2}{l}{ Intercept Break } & \multicolumn{2}{c}{ Trend Break } & \multicolumn{2}{c}{ Intercept and Trend Break } \\
\cline { 2 - 7 } & t-stats & Break Dates & t-stats & Break Dates & t-stats & Break Dates \\
ZA & $-4.612(1)$ & 1967 & $-4.177(1)$ & 1947 & $-4.943(1)$ & 1967 \\
LP & $-6.531(1) * *$ & 1966,2000 & $-5.085(1)$ & 1957,1974 & $-5.740(1)$ & 1989,2004 \\
\hline
\end{tabular}

Table 5. Breakpoint Unit Root Tests (Based on ADF)

Notes: (1) The critical values are obtained from Zivot and Andrews (1992) for ZA test, from Lumsdaine and Papell (1997) for LP test. (2) The critical values of $1 \%$ and $5 \%$ significance levels in ZA test are -5.34 and -4.80 for models with only intercept break, -4.93 and -4.42 for models with only trend break and -5.57 and -5.08 for models with intercept and trend break, respectively. This values -6.94 and $-6.24,-7.24$ and -6.65 and -7.34 and -6.82 for LP test with the same models. (3)These tests include both intercept and trend. (4) The values in parenthesis represent the optimal lag length determined by the GtoS approach. The maximum lag length is 8. (5) ** indicates that the null hypothesis is rejected at 5\% significance level. (6) The trimming parameter is 0.15 . (7) ZA and LP test is performed by EViews 10 and RATs 8.0, respectively. 


\begin{tabular}{lllll}
\hline \multirow{2}{*}{ Tests } & \multicolumn{2}{l}{ Intercept Break } & \multicolumn{2}{l}{ Intercept and Trend Break } \\
\cline { 2 - 5 } LS1 & t-stats & Break Dates & t-stats & Break Dates \\
LS2 & $-1.241(1)$ & 1982 & $-3.321(1)$ & 1946 \\
\hline
\end{tabular}

Table 6. Breakpoint Unit Root Tests (Based on LM)

Notes: (1) The critical values are obtained from Lee and Strazicich (2004) for LS1 test, from Lee and Strazicich (2003) for LS2 test. (2) The critical values of $1 \%$ and 5\% significance levels in LS1 test are -4.24 and -3.57 for models with only intercept break, -5.15 and -4.45 for models with intecept and trend break, respectively. This values -5.44 and $-3.84,-6.41$ and -5.74 for LS2 test with the same models. (3)These tests include both intercept and trend. (4) The values in parenthesis represent the optimal lag length determined by the GtoS approach. The maximum lag length is 8. (5) The trimming parameter is 0.15 . (6) These tests are carried out with RATs 8.0.

\begin{tabular}{lll}
\hline Tests & Intercept & Intercept and Trend \\
\hline KSS & $2.120(2)$ & $2.127(2)$ \\
Sollis & $3.975(2)$ & $3.397(2)$ \\
\hline
\end{tabular}

Table 7. Nonlinear Unit Roots Tests

Notes: (1) The critical values are obtained from Kapetanios et al. (2003) for KSS test, from Sollis (2009) for Sollis test. (2) The critical values of $1 \%$ and $5 \%$ significance levels in KSS test are -3.48 and -2.93 for models with only intercept break, -3.93 and -3.40 for models with intecept and trend break, respectively. This values -6.89 and $-4.89,-8.80$ and -6.55 for Sollis test with the same models. (3) The number of observations for the Sollis test is accepted to be 50. (4) Sollis test is based on F statistics. (5) The values in parenthesis represent the optimal lag length determined by the GtoS approach. The maximum lag length is 8. (6) These tests are performed by EViews 10.

\begin{tabular}{llllllll}
\hline $\mathbf{m}$ & & $\mathbf{0 . 4 5}$ & $\mathbf{0 . 5 0}$ & $\mathbf{0 . 5 5}$ & $\mathbf{0 . 6 0}$ & $\mathbf{0 . 6 5}$ & $\mathbf{0 . 7 0}$ \\
\hline \multirow{2}{*}{ Geweke and } & $\mathrm{d}^{*}$ & 0.22 & 0.00 & -0.11 & -0.05 & 0.06 & 0.06 \\
Porter-Hudak & t-stats & 0.79 & 0.00 & -0.58 & -0.31 & -0.46 & -0.58 \\
& Prob. & 0.47 & 1.00 & 0.58 & 0.76 & 0.65 & 0.57 \\
\multirow{2}{*}{ Robinson } & $\mathrm{d}^{*}$ & 0.21 & 0.00 & -0.01 & -0.05 & -0.06 & -0.06 \\
& t-stats & 0.79 & -0.01 & -0.07 & -0.31 & -0.47 & -0.64 \\
& Prob. & 0.46 & 0.99 & 0.95 & 0.76 & 0.65 & 0.53 \\
Phillips & d* & 0.12 & -0.07 & -0.16 & -0.10 & -0.12 & -0.10 \\
& t-stats & 0.43 & -0.30 & -0.85 & -0.61 & -0.89 & -0.96 \\
& Prob. & 0.68 & 0.77 & 0.41 & 0.55 & 0.39 & 0.35 \\
\hline
\end{tabular}

Table 8. ARFIMA Tests

Notes: (1) m shows the number of optimal ordinates. (2) These tests are carried out with Stata 14.2.

\begin{tabular}{|c|c|c|c|c|c|c|}
\hline \multicolumn{6}{|c|}{ Individual Tests } & \multirow{2}{*}{$\begin{array}{l}\text { Joint Test } \\
\operatorname{Max}|z|\end{array}$} \\
\hline $\mathbf{k}$ & 5 & 10 & 15 & 20 & 25 & \\
\hline \multicolumn{7}{|c|}{ Lo and MacKinlay Test } \\
\hline VR(k) & 0.997 & 0.872 & 0.770 & 0.845 & 0.836 & \\
\hline $\mathbf{Z 1}$ & -0.015 & -0.614 & -0.529 & -0.304 & -0.285 & 0.614 \\
\hline Prob. & 0.993 & 0.685 & 0.718 & 0.842 & 0.845 & 0.901 \\
\hline $\mathbf{Z 2}$ & -0.010 & -0.484 & -0.443 & -0.267 & -0.261 & 0.484 \\
\hline Prob. & 0.989 & 0.704 & 0.686 & 0.819 & 0.832 & 0.918 \\
\hline \multicolumn{7}{|c|}{ Wright Test } \\
\hline VR(k) & 1.270 & 1.078 & 1.052 & 1.061 & 1.002 & \\
\hline $\mathbf{R 1}$ & 1.204 & 0.225 & 0.120 & 0.120 & 0.003 & 1.204 \\
\hline Prob. & 0.239 & 0.863 & 0.953 & 0.949 & 1.000 & 0.460 \\
\hline $\operatorname{VR}(\mathbf{k})$ & 1.145 & 0.911 & 0.870 & 0.884 & 0.819 & \\
\hline $\mathbf{R 2}$ & 0.644 & -0.258 & -0.299 & -0.228 & -0.315 & 0.644 \\
\hline Prob. & 0.556 & 0.847 & 0.829 & 0.896 & 0.875 & 0.869 \\
\hline $\operatorname{VR}(k)$ & 1.455 & 1.419 & 1.399 & 1.368 & 1.320 & \\
\hline $\mathbf{S}$ & 2.023 & 1.209 & 0.915 & 0.723 & 0.557 & 2.023 \\
\hline Prob. & 0.046 & 0.291 & 0.486 & 0.653 & 0.779 & 0.057 \\
\hline
\end{tabular}

Table 9. Variance Ratio Tests

Notes: (1) VR(k) indicates the variance ratio in lag $k$. (2) Z1 and Z2 show the Z statistics proposed by Lo and MacKinlay (1988) calculated under the assumption of homoskesdacity and heteroskesdacity, respectively. $R 1, R 2$ and $S$ show the $Z$ statistics calculated by Wright (2000), based on sign, sign score, and ranks, respectively. The distribution of variance ratios is obtained 
by the wild bootstrap technique proposed by Kim (2006) in all five tests, (3) Max $|z|$ shows Chow and Denning (1993) test statistics. (4) These tests are performed by EViews 10.

\section{Conclusion}

Although the unemployment hysteresis and natural unemployment rate hypotheses are one of the most studied subjects on macroeconomics, these concepts are not fully understood due to the differentiation of the techniques and variables used. Therefore, the results are re-examined in favor of the natural unemployment rate hypothesis with every new technique developed in the field of econometrics and the results are generally in favor of unemployment hysteresis especially in the studies using long-term data sets. In this study, the stability of unemployment rate is investigated in Turkey with the data set covering approximately a century and starting from 1923.

The stability of the unemployment rate is examined the unit root tests, variance ratio tests and fractional integration models by following the studies in the literature. Almost all tests and models indicate that the unemployment rate series is not stationary. These findings show that the shocks in the economy and the stabilization policies implemented lead to permanent changes in the natural rate of unemployment. While the unemployment hysteresis leads to increasing costs in reducing inflation, it also reveals the necessity of structural reforms to reduce increased unemployment as a result of inflation control or changes in structural factors. In order to eliminate the effect of this hysteresis on unemployment, it is necessary to give weight to the expansionary monetary and fiscal policies, which in the short term may be costly, but in the long term, this impact can be eliminated.

\section{References}

- $\quad$ Banerjee, A., Urga, G. (2005). Modelling Structural Breaks, Long Memory and Stock Market Volatility: An Overview. Journal of Econometrics, 129(1): 1-34.

- $\quad$ Baum, C. F., Barkoulas, J. T., Caglayan, M. (1999). Long Memory or Structural Breaks: Can Either Explain Nonstationary Real Exchange Rates under the Current Float?. Journal of International Financial Markets, Institutions and Money, 9(4), 359-376.

- Blanchard, O. J., \& Summers, L. H. (1986). Hysteresis and the European Unemployment Problem. NBER Macroeconomics Annual, 1, 15-78.

- Bulutay, T. (1995). Employment, Unemployment and Wages in Turkey. International Labour Organization.

- Chang, T. (2011). Hysteresis in Unemployment for 17 OECD Countries: Stationary Test with a Fourier Function. Economic Modelling, 28(5), 2208-2214.

- Chow, K.V., Denning, K.C. (1993). A Simple Multiple Variance Ratio Test. Journal of Econometrics, 58(3): 385-401.

- Christopoulos, D. K., \& León-Ledesma, M. A. (2007). Unemployment Hysteresis in EU Countries: What Do We Really Know About It?. Journal of Economic Studies, 34(2), 80-89.

- Clemente, J., Montanes, A., Reyes, M. (1998). Testing for a Unit Root in Variables with a Double Change in the Mean. Economics Letters, 59(2): 175-182.

- Cochrane, J. H. (1988). How Big is the Random Walk in GNP?. Journal of Political Economy, 96(5), 893920 .

- Crato, N., \& Rothman, P. (1996). Measuring Hysteresis in Unemployment Rates with Long Memory Models. Greenville, Carolina del Sur: Department of Economics, East Carolina University.

- Dickey, D. A., Fuller, W. A. (1981). Likelihood Ratio Statistics for Autoregressive Time Series with a Unit Root. Econometrica: Journal of the Econometric Society, 1057-1072.

- $\quad$ Elliott, G., Rothenberg, T., Stock, J. H. (1996). Efficient Tests for an Autoregressive Unit Root. Econometrica, 64(4): 813-836.

- Friedman, M. (1968). The Role of Monetary Policy.

- Fuller, W.A. (1976). Introduction to Statistical Time Series. Wiley: New York.

- Geweke J., Porter-Hudak, S. (1983). The Estimation and Application of Long Memory Time Series Models. Journal of Time Series Analysis, 4(4): 221-238.

- Gomes, F., \& da Silva, C. G. (2008). Hysteresis vs. Natural rate of Unemployment in Brazil and Chile. Applied Economics Letters, 15(1), 53-56.

- Gozgor, G. (2012). Hysteresis in Regional Unemployment Rates in Turkey. International Journal of Economics and Finance, 4(9), 175. 
- Granger, C. W. (1980). Long Memory Relationships and the Aggregation of Dynamic Models. Journal of econometrics, 14(2), 227-238.

- Granger, C. W., Joyeux, R. (1980). An Introduction to Long-Memory Time Series Models and Fractional Differencing. Journal of Time Series Analysis, 1(1), 15-29.

- Güloğlu, B., \& İspir, M. S. (2011). Is Natural Rate of Unemployment or Hysteresis? Sector-Specific Panel Unit Root Test Analysis for Turkey. Ege Academic Review, 11(2), 205-215.

- Gustavsson, M., \& Österholm, P. (2006). Hysteresis and Non-linearities in Unemployment Rates. Applied Economics Letters, 13(9), 545-548.

- Hall, A. (1994). Testing for a Unit Root in Time Series with Pretest Data-Based Model Selection. Journal of Business and Economic Statistics, 12(4): 461-470.

- Hosking, J. R. (1981). Fractional Differencing. Biometrika, 68(1), 165-176.

- Johansen, K. (2002). Hysteresis in Unemployment: Evidence from Norwegian Counties.

- Kapetanios, G., Shin, Y., Snell, A. (2003). Testing for a Unit Root in the Nonlinear STAR Framework. Journal of Econometrics, 112(2): 335-346.

- Kurita, T. (2010). A Forecasting Model for Japan's Unemployment Rate. Eurasian Journal of Business and Economics, 3(5), 127-134.

- $\quad$ Kwiatkowski, D., Phillips, P.C.B., Schmidt, P., Shin, Y. (1992). Testing the Null Hypothesis of Stationarity against the Alternative of a Unit Root. Journal of Econometrics, 54(1): 159-178.

- $\quad$ Lee, H. Y., Wu, J. L., \& Lin, C. H. (2010). Hysteresis in East Asian Unemployment. Applied Economics, 42(7), 887-898.

- $\quad$ Lee, J., Strazicich, M. C. (2003). Minimum Lagrange Multiplier Unit Root Test with Two Structural Breaks. Review of Economics and Statistics, 85(4): 1082-1089.

- Lee, J., Strazicich, M. C. (2004). Minimum LM Unit Root Test with One Structural Break. Appalachian State University Department of Economics Working Paper, No: 04-17.

- $\quad$ Lindbeck, A., \& Snower, D. J. (1986). Wage Setting, Unemployment, and Insider-Outsider Relations. The American Economic Review, 76(2), 235-239.

- $\quad$ Lo, A.W., MacKinlay, A. C. (1988). Stock Market Prices Do Not Follow Random Walks: Evidence From a Simple Specification Test. Review of Financial Studies, 1(1): 41-66.

- $\quad$ Lumsdaine, R. L., Papell, D. H. (1997). Multiple Trend Breaks and the Unit Root Hypothesis. Review of Economics and Statistics, 79(2): 212-218.

- Maeso-Fernandez, F. (1998). Econometric Methods and Purchasing Power Parity: Short and Long-Run PPP. Applied Economics, 30(11): 1443-1457.

- Neudorfer, P., Pichelmann, K., \& Wagner, M. (1990). Hysteresis, NAIRU and Long Term Unemployment in Austria. In Hysteresis Effects in Economic Models (pp. 109-121). Physica-Verlag HD.

- $\quad$ Ng, S., Perron, P. (1995). Unit Root Test in ARMA Models with Data Dependent Methods for the Selection of the Truncation Lag. Journal of the American Statistical Association, 90(429): 268-281.

- Ng, S., Perron, P. (2001). Lag Length Selection and the Construction of Unit Root Tests with Good Size and Power. Econometrica, 69(6): 1519-1554.

- Özkan, Y., \& Altınsoy, A. (2015). İşsizlik ve İstihdamda Histeri Etkisi (Türkiye, 1988-2014). Siyaset, Ekonomi ve Yönetim Araştırmaları Dergisi.

- Perron, P. (1989). The Great Crash, the Oil Price Shock and the Unit Root Hypothesis. Econometrica, 57(6): 1361-1401.

- $\quad$ Perron, P. (1997). Further Evidence from Breaking Trend Functions in Macroeconomic Variables. Journal of Econometrics, 80(2): 355-385.

- Perron, P., Vogelsang, T. J. (1992). Nonstationarity and Level Shifts with an Application to Purchasing Power Parity. Journal of Business and Economic Statistics, 10(3): 301-320.

- Phelps, E. S. (1967). Phillips Curves, Expectations of Inflation and Optimal Unemployment over Time. Economica, 254-281.

- $\quad$ Phelps, E. S. (1968). Money-wage Dynamics and Labor-market Equilibrium. Journal of Political Economy, 76(4, Part 2), 678-711.

- $\quad$ Phelps, E. S. (1994). Structural Slumps: The Modern Equilibrium Theory of Unemployment, Interest, and Assets. Harvard University Press. 
- $\quad$ Phillips, P. C. B. (1999a), Discrete Fourier Transforms of Fractional Processes. Yale University Cowles Foundation for Research in Economics Working Paper, No: 1243.

- $\quad$ Phillips, P. C. B. (1999b). Unit Root Log Periodogram Regression. Yale University Cowles Foundation for Research in Economics Working Paper, No: 1244.

- Pissarides, C. A. (1992). Loss of Skill during Unemployment and the Persistence of Employment Shocks. The Quarterly Journal of Economics, 107(4), 1371-1391.

- $\quad$ Robinson, P. M. (1995). Log-Periodogram Regression of Time Series with Long Range Dependence. Annals of Statistics, 23(3): 1048-1072.

- $\quad$ Røed, K. (1996). Unemployment Hysteresis-macro Evidence from 16 OECD Countries. Empirical Economics, 21(4), 589-600.

- $\quad$ Schmidt, P., Phillips, P. C. B. (1992). LM Tests for a Unit Root in the Presence of Deterministic Trends. Oxford Bulletin of Economics and Statistics, 54(3): 257-287.

- Sollis, R. (2009). A Simple Unit Root Test against Asymmetric STAR Nonlinearity with an Application to Real Exchange Rates in Nordic Countries. Economic Modelling, 26(1): 118-125.

- $\quad$ Song, F. M., \& Wu, Y. (1998). Hysteresis in Unemployment: Evidence from OECD Countries. The Quarterly Review of Economics and Finance, 38(2), 181-192.

- Stanley, T. D. (2004). Does Unemployment Hysteresis Falsify the Natural Rate Hypothesis? A Metaregression Analysis. Journal of Economic Surveys, 18(4), 589-612.

- Villeneuve, J. F., \& Handa, J. (2006). Purchasing Power Parity as a Long-term Memory Process: Evidence from Canada. Applied Financial Economics, 16(1-2), 109-117.

- Wright, J. H. (2000). Alternative Variance-Ratio Tests Using Ranks and Signs. Journal of Business and Economic Statistics, 18(1): 1-9.

- Yılancı, V. (2009). Yapısal Kırılmalar Altında Türkiye için İşsizlik Histerisinin Sınanması.

- Zivot, E., Andrews, D. W. K. (1992). Further Evidence on the Great Crash, the Oil Price Shock and the Unit Root Hypothesis. Journal of Business and Economic Statistics, 10(3): 251-270. 